\title{
後腹膜 $\boldsymbol{\alpha}$-fetoprotein 産生未分化癌の 1 例
}

武市牧子兵庫医科大学第 2 外科
蕒 琴 浦 義 尚 宇都宮 譲 二
桜 井 一 成 植 松 邦 夫

後腹膜に発生し特異な病理組織を呈する未分化癌の 1 例を報告した．本症例は47歳男 性で慢性肝炎経過観察中に, AFP $810 \mathrm{ng} / \mathrm{ml}$, CA125 6,200ng/ml と高值をみとめた. 腹部 CT, 血管造影では膵胆道系そのものには明らかな異常を認めなかったが膵頭部周

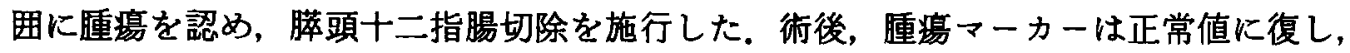
経過は順調であったが，病理組織学的検討において，腫瘍と考克られていた部はすべて リンパ節腫大でその中に肝細胞に類似した部を認め“肝様腫場”を最も疑った。しかし， 原発葴器不明のため, 確定診断を得られず，著者らは本症例を，後腹膜 AFP 産生未分化 癌として報告した。

索引用語：AFP 産生腫煌, 肝様腫煌

\section{緒 言}

AFP 産生腫場については原発性肝癌・胎児性癌以 外，胃癌を中心に臨床・免疫学的にさまざまな報告例 があるが, 後腹膜に扣ける AFP 産生腫湯は極めて稀 である。.今回われわれは術前 AFP 810ng/ml, CA125 $6,200 \mathrm{ng} / \mathrm{ml}$ と高値を示した，後腹膜に発生した未分 化癌について報告する。

\section{症例}

症 例：47歳, 男性.

主訴：腹部腫瘤。

現病歴：昭和55年より, 非 A 非 B 型慢性肝炎で 1 年間入院し，その後外来で経過観察していたところ， 昭和63年 8 月, AFP $500 \mathrm{ng} / \mathrm{ml}$ 以上, CEA $11.2 \mathrm{ng} / \mathrm{ml}$ と上昇を認めた。平成 1 年 1 月，腹部 CT にて膵頭部 周团に腫瘤を認め, 精査目的で入院となった。入院時, 自覚症状はまったく認めなかった。

既往歴：特になし。

家族歷：父；肝硬変で死亡. 兄；肝癌で死亡.

入院時現症：全身状態良好。眼球打よび眼検結膜に 黄㾝，賀血認めず。心肺系異常なし。

腹部所見: 平坦, 軟. 右乳線上に 3 横指肝を触知。 脾および腎は触知せず。
表 1 入院時検查成維

\begin{tabular}{|c|c|c|c|}
\hline WBC & $7200 / \mathrm{mm}^{3}$ & AMY & $347 \mathrm{IU}$ \\
\hline $\mathrm{RBC}$ & $482 \times 10^{4} / \mathrm{mm}^{3}$ & ICG $15^{\circ}$ & $4 \%$ \\
\hline $\mathrm{Hb}$ & $14.7 \mathrm{~g} / \mathrm{dl}$ & $\mathrm{K}$ 值 & 0.131 \\
\hline $\mathrm{Ht}$ & $45.8 \%$ & HBs & $(-)$ \\
\hline \multirow[t]{2}{*}{ plt } & $23.1 \times 10^{4} / \mathrm{mm}^{3}$ & $\mathrm{HBsAb}$ & $(-)$ \\
\hline & & CRP & $2+$ \\
\hline TP & $8.35 \mathrm{~g} / \mathrm{dl}$ & & \\
\hline Alb & $4.09 \mathrm{~g} / \mathrm{dl}$ & 畽管マーカー & \\
\hline GOT & $23 \mathrm{ku}$ & AFP & $671 \mathrm{ng} / \mathrm{ml}$ \\
\hline GPT & $33 \mathrm{ku}$ & CEA & $15.1 \mathrm{ng} / \mathrm{ml}$ \\
\hline$A l-p$ & $2.87 \mathrm{BLU}$ & CA125 & $5050 \mathrm{U} / \mathrm{ml}$ \\
\hline$r$-GTP & $23 \mathrm{IU}$ & CAl9-9 & $21 \mathrm{U} / \mathrm{ml}$ \\
\hline $\operatorname{chE}$ & $5.2 \mathrm{IU}$ & エラスターゼ1 & $440 \mathrm{ng} / \mathrm{dl}$ \\
\hline T-Bil & $0.31 \mathrm{mg} / \mathrm{dl}$ & $\beta_{2}$ マイクロタロブ & ソ $2.9 \mu \mathrm{g} / \mathrm{ml}$ \\
\hline ZTT & $22.9 \mathrm{U}$ & TPA & $121 \mathrm{U} / 1$ \\
\hline TTT & $4.80 \mathrm{U}$ & & \\
\hline
\end{tabular}

入院時検查成績（表 1)：AFP，CEA，CA 125は高 值, エラスターゼ $1 ， \beta_{2}$ マイクログロブリン, TPA は 軽度上昇, CA19-9は正常值を示した。

\section{画像診断}

腹部 CT 所見：膵・下大静脈・大動脈との境界不明瞭 な一部 enhanceされる多房性の低吸収域を膵頭部お よび十二指腸背側に認めた（図 1)，CT 上の診断は後 腹膜腫瘍であった。

血管造影所見：胃十二指腸動脈枝, 後脺十二指腸動 


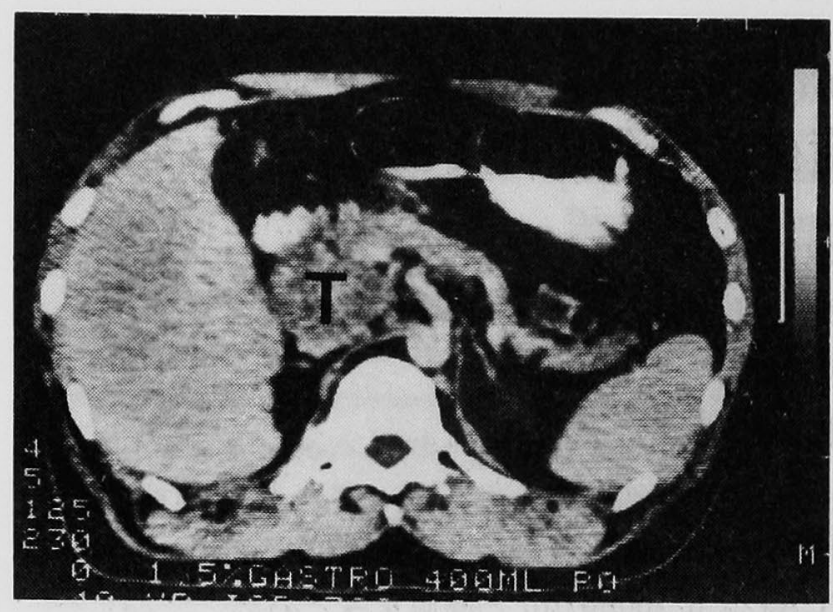

図 1 enhanced CT：膵頭部および十二指腸背側に 一部 enhance される多房性低吸収域(T)を認めた。

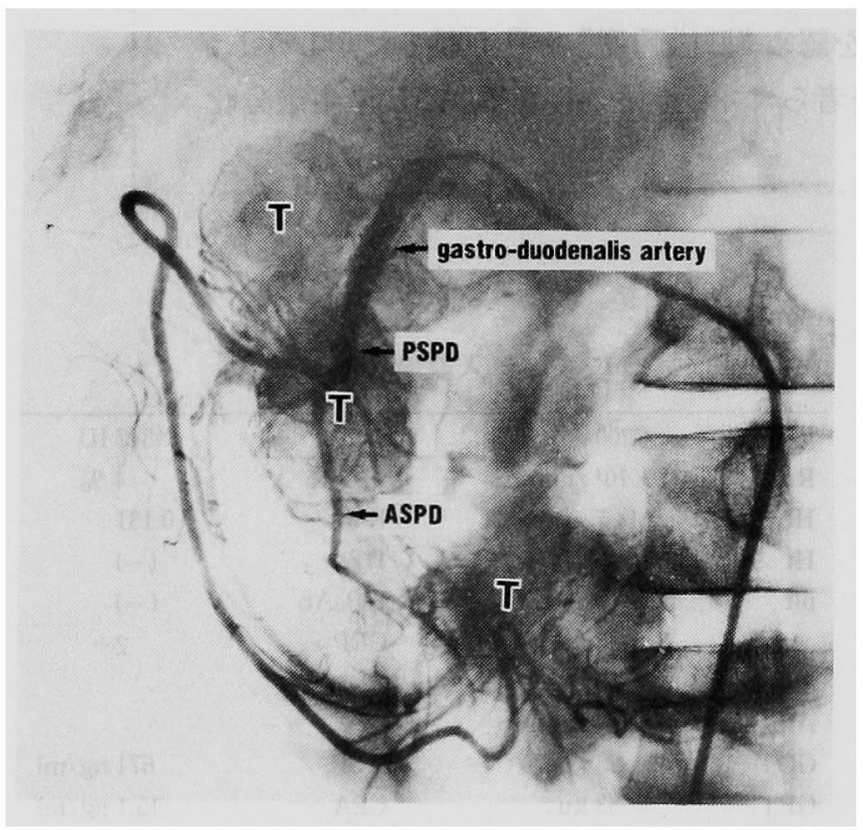

図 2 血管造影：腹腔動脈からの血管造影で胃十二指 腸動脈枝, 後上膵十二指腸動脈の十二指腸枝拉よび 胃大網動脈を栄養動脈とする腫瘍濃染像 $(\mathrm{T})$ を認め た。

脈の十二指腸枝，胃大網動脈を栄養動脈とする腫瘍濃 染像を認めた。血管造影上の診断は悪性リンパ腫で あった（図 2 ).

上部消化管 $\mathbf{X}$ 線透視所見：十二指腸球部から下行 脚 Vater 乳頭まで，背部より王排を認めた。また同部 位に淡いバリウムの溜りを認め，腫湯の浸潤が疑われ た。

胃内視鏡所見：胃体上部前壁および十二指腸 Vater 乳頭部後壁にも壁外珄王排を認めた。十二指腸 Vater 乳頭部の粘膜面に発赤およびビランを認めたため，同

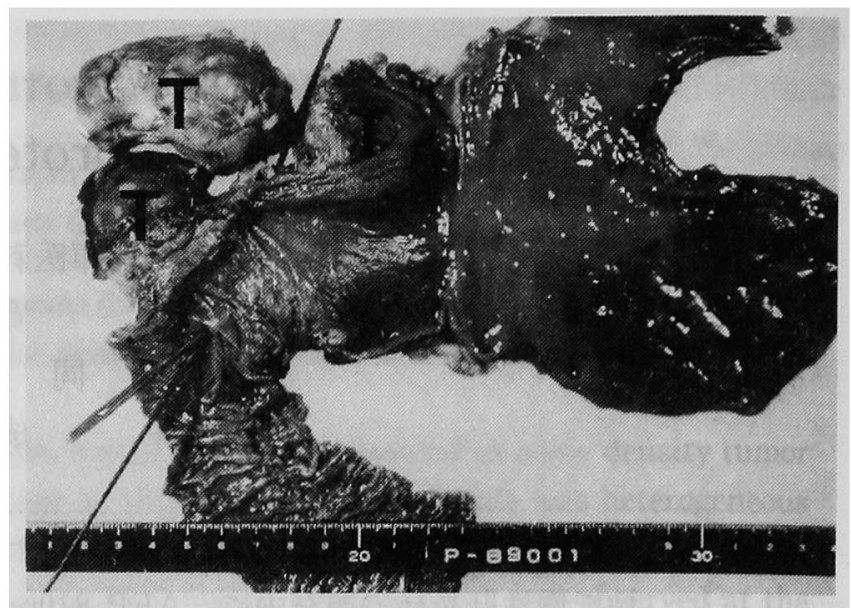

図 3 手術標本：腫瘍の本体はNo. $5,8 \mathrm{a} 8 \mathrm{p}, 12 \mathrm{a}_{1} \mathrm{a}_{2}$, $12 \mathrm{p}_{1} \mathrm{p}_{2}, 13 \mathrm{ab}$ のリンパ節腫大であった。

部の生検を行ったが，正常十二指腸組䅧のみで悪性腫 瘍細胞はみられなかった。

内視鏡的逆行性膵胆管造影所見：膵管 - 胆管ともに 壁整で管径や走行に異常はみられなかった。

臨床経過：術前の画像診断では確定診断がつかず, 後腹膜腫瘍，あるいは悪性リンパ腫として平成 1 年 3 月試験開復を施行。腫瘍の本体は弾性軟の腫大したり ンパ節であった．庫大したリンパ節はNo. 8, 12, 13 ab, 14にみられた. No. 8のリンパ節を術中迅速病理検 査に提出したが末分化癌の転移であること以上の質的 診断がつかず一旦閉腹。原発巣は依然として不明で あったしかし，1）画像診断より肝・腎に異常所見が みられなかった，2）試験開腹時にも肝・腎・脾に異常 所見を認めなかった.3）膵に関しては画像診断や試験 開腹時に膵本体には明らかな異常を認めなかったが， 膵頭部周囲の腫大したリンパ節が腫怚の本体であっ た.4）リンパ節 No. 8の病理所見でシート状に配列す る大型の細胞をみた。ささらには類上皮細胞や Langhans 型巨細胞の共存を認めた。以上より, 膵頭部原発の 癌を疑い“膵頭部癌疑い”の診断でリンパ節郭清をか ねて, 平成 1 年 4 月, 膵頭十二指腸切除術を施行した。

手術所見：畽瘍は淡黄色弾性軟で脺本体に明らかな 異常を認めなかったが，膵頭部を中心にその周辺を一 塊となった腫瘤がとり囲んでいた。その本体はNo. 5 , 8ap, $12 \mathrm{a}_{1} \mathrm{a}_{2}, 12 \mathrm{p}_{1} \mathrm{p}_{2}, 13 \mathrm{ab}$ のンパ節腫大で, これが 多房性腫瘤として画像上とらえられていたと考光られ た。手術は膵頭部を門脈左側約 $1 \mathrm{~cm}$ で離断し，膵頭部 および腫瘤を一塊として摘出した。なお，腫瘍との豩 離に関しては腫瘍と下大静脈・大動脈・門脈・上腸間 膜動静脈など,いずれの脈管とも剝離は容易であった。 


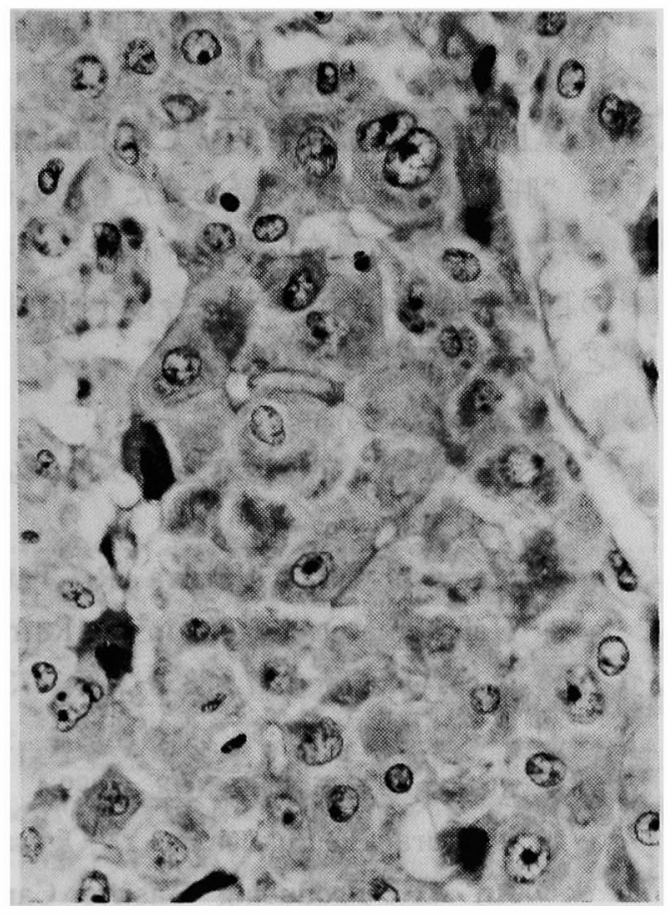

a)

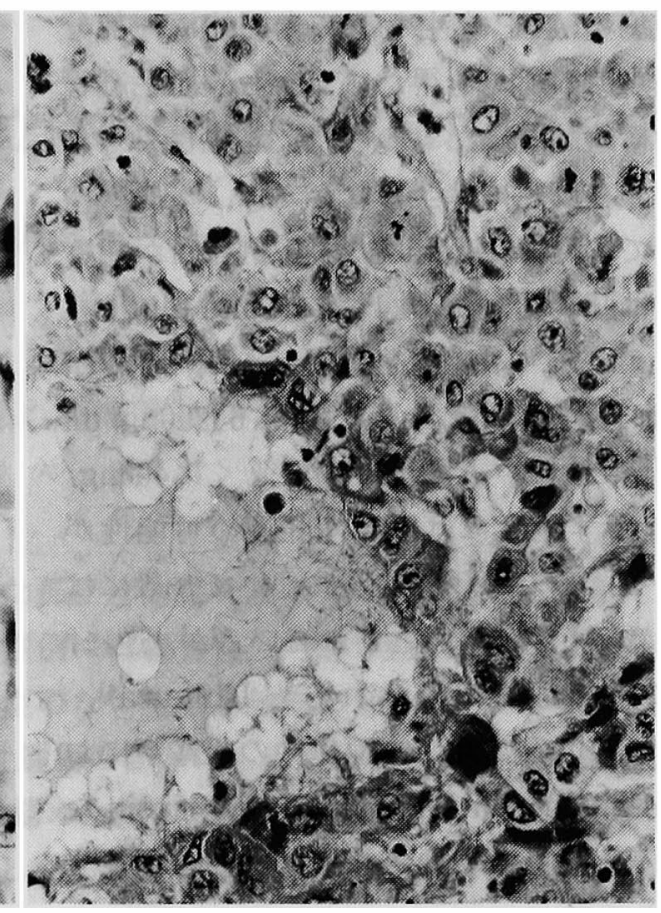

b)

图 4a 病理組織像：腫瘍組織はシート状配列にみられた。核は胞状で巨核のものもみ とめた。細胞質は比較的豊富で好酸性をしめした。また，一部のリンバ節で脈管構 造を認めた。(HE 染色, $2.5 \times 40)$ ， b 病理組織像：また，腫瘍細胞が血管腔に密に 接する像むみられた。（HE染色, $2.5 \times 20$ )

\section{表 2 術後経過}

\begin{tabular}{l|c|c|c}
\hline & 第 8 病日 & 第18病日 & 6 力月後 \\
\hline AFP & 81 & 3 & $3 \mathrm{ng} / \mathrm{ml}$ (正常25以下) \\
CEA & 4.4 & 1 & $2.4 \mathrm{ng} / \mathrm{ml}$ (正常3.0以下) \\
CA125 & 550 & 7 & $6 \mathrm{U} / \mathrm{ml}$ (正常35以下) \\
エラスターゼ1 & 946 & 437 & $28 \mathrm{ng} / \mathrm{dl}$ (正常70-100) \\
\hline
\end{tabular}

再建はChild 変法とした（図 3).

術後経過：術後経過は良好で，第25病日に軽快退院 した．患者は現在，再発の兆候なく元気に復職してお り，また術後第18病日および 6 カ月後に招ける腫瘍 マーカーは，表 2 のごとく，現在も再上昇認めず，画 像診断上る再発を認めていない.

病理学的所見：肉眼的には腫瘍は膵頭部を中心にそ の周囲をとり囲んでいたが，膵本体には明らかな異常 を認めなかった。病理学的な検索に颃いてす膵頭部に 明らかな異常を認めなかった，得られた細胞はすべて リンパろ胞をふくむリンパ節とみられる組織中に， シート状配列にみられた。その細胞核は胞状で巨核の ものもみられ，その細胞質は比較的豊富で好酸性を示 した，さらには類上皮細胞や Langhans 型巨細胞の共 存をみとめた。 また，一部のリンパ節で細胞間に脈管
状構造をみた（図 4a)．その他，腫瘍細胞が血管腔に密 に接する像もみられた(図 4b). 即ち, 肝細胞癌類似の 像が得られた. 電顕でも明らかに microvilli をみとめ, 上皮性性格を有していた。酵素抗体法ではCEA, AFP, CA125, $\alpha_{1}$-antitripsin, $\alpha_{1}$-antichymotripsin な どの陽性像がえられた，以上より，診断は原発不明の リンパ節転移性末分化癌とした。

\section{考察および結語}

肝様腫瘍についてのいくつかの報告例があり"，そ の局在としては胆变・肝三角勤带・脾・小網・肺・後 腹膜・卵巣・膵・胃などである.この異所性の同定に は, 原発葴器が肝でないこと, 肝癌の転移でないこと が必要である。また，わが国の原発性肝癌患者の $80 \%$ が肝硬変を伴うために肝硬変の有無る参考となる。肝 細胞性の同定は形態と AFP 産生性がある，血中 AFP の上昇, 光顕電顕での AFP 陽性染色, 加えて尰瘍細胞 が豊かな好酸性胞体をむち, 光顕的に肝細胞に似るこ と，また胆汁産生も大切な要素である。その他 AFP 以 外の血清蛋白, $\alpha_{1}$-antitripsin, $\alpha_{1}$-antichymotripsin な との陽性染色所見もある。本症例では画像診断, 肉眼 所見などから原発性肝癌や肝癌の転移でないことが確 認されており，また肝硬変の所見はなかった。病理学 
的見地からは腫湯の AFP 産生を認め光顕的に一部分 ながら肝細胞癌類似の所見を得た。しかし, 胆毛細管 を思わせる脈管構造を認めたものの胆汁産生はみられ ず正常肝組織の存在確定には至らなかった．後腹膜の

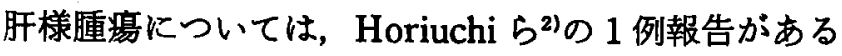
が，この症例では肝硬変様の細胞および bile plug が， 認められていた，また，本症例を腫瘍マーカーの点か らみると汭，術前 AFP 810ng/ml, CA125 6,200ng/ml と高値を示していた。血中 AFP の上昇, とくに $400 \mathrm{ng} /$ $\mathrm{ml}$ 以上の高值を示す場合には原発性肝癌の可能性が 高いとされている。一方，肝様腫湯について一般には 原発性肝癌よりは AFP が低いとされているが，逆に， 数千 $\mathrm{ng} / \mathrm{ml}$ をこえる症例むみられると Ishikura“), Akai ${ }^{5)}$ らは報告している。 また, 本症例中の組織中にお いて AFP, $\alpha_{1}$-antitripsin, $\alpha_{1}$-antichymotripsin な どの血清蛋白含有という点からみても肝尰崵を否定す るにはいたらない。

ところで卵巣腫湯について特異的であるCA125の 著明な上昇については原因不明である。また CA125は 肝胆脺系腫瑝で40から70\%の陽性率を示すが3)，やは り膵胆道系睡湯で陽性率80\%とされる CA19-9が正常 値を示している点は相反するものである，ただし， CA125は良性腫湯での偽陽性率は低く，また CEA，
AFPの值からみても本症例が悪性腫瘍であることが 示唆される。

以上上り，本症例に関しては Ishikura ら゙が提唱す る“肝様腫場”が最も疑われたものの確定診断にはい たらなかった．現在，腫瑒マーカーの再上昇や画像上 の再発を認めていないか，今啳十分な経過観察が必要 といえる症例である。

$$
\text { 文献 }
$$

1）石原 浩：肝様缠瘍，医のあゆみ $143 ： 557-$ 561,1987

2) Horiuchi N, Kitamura $R$, Tateishi et al: Hepatoma Originated in the Retroperitoneal S pace. Oncology $27: 235-243,1973$

3）石井 勝, 谷内 昭, 有村佳昭他：免度血清検査, medica $26: 1836-1848,1989$

4) Ishikura $H$, Fukasawa $Y$, Ogasawara et al: An AFP-Producing Gastric Carinoma With Features of Hepatic Differentiation. Cancer 56 : $840-848,1985$

5) Akai S, Kato K: Serum $\alpha$-FetoproteinPositive Stomach Cancer. GANN Monograph on Cancer Reserch $14:$ 149-154, 1973

\title{
A CASE OF RETROPERITONEAL UNDIFFERENTIATED CARCINOMA WITH A HIGH LEVEL OF AFP AND CA125
}

\author{
Makiko TAKECHI, Hiroshi ASHIDA, Yoshinao KOTOURA, Kazunari SAKURAI*, \\ Kunio UEMATSU* and Joji UTSUNOMTYA \\ Second Department of Surgery, Hyogo College of Medicine \\ *Department of Hospital Pathology, Hyogo College of Medicine
}

A case of retroperitoneal undifferentiated carcinoma was reported. The patient was a 47-year-old man suffered from chronic hepatitis (non A non B) for several years. In the beginning of the last year, serum levels of AFP and CA125 increased markedly. Computed tomography showed several masses surrounded the head of the pancreas. Pancreatico-duodenectomy was performed for exclusion of the tumors, which were enlarged lymphnodes. Those tumor markers decreased to the normal level postoperatively. The histological findings of small portion of the tumor showed a hepatocellular-like carcinoma and so its diagnosis of "hepatoid carcinoma" was doubtful. As we could get unknown origin, this case was reported here as that of AFP producing retroperitoneal undifferentiated carcinoma. 